\title{
Determination of relative tectonic activity of the Honaz fault (SW Turkey) using geomorphic indices
}

\author{
Jeomorfik indisler kullanılarak honaz fayı'nın (GB Türkiye) göreceli \\ tektonik aktivitesinin belirlenmesi
}

\author{
Savaş TOPAL ${ }^{1 *}$ (D), Mehmet ÖZKUL ${ }^{2}$ iD \\ 1,2Department of Geological Engineering, Engineering Faculty, Pamukkale University, Denizli, Turkey. \\ savastopal@pau.edu.tr, mozkul@pau.edu.tr
}

Received/Geliș Tarihi: 09.03.2017, Accepted/Kabul Tarihi: 24.04.2017

doi: $10.5505 /$ pajes.2017.18199

* Corresponding author/Yazıșllan Yazar Research Article/Araștırma Makalesi

\begin{abstract}
In this study, in order to determine relative tectonic activity of the Honaz Fault, geomorphic indices such as triangular facets, drainage basin asymmetry (AF), hypsometric integral (HI), drainage basin shape (Bs), ratio of valley-floor width to valley height (Vf), and mountain front sinuosity ( $\mathrm{Smf}$ ) have been calculated. The results of the indice analysis were evaluated and then index of the relative tectonic activity (Iat) were re-evaluated. Base on the different Iat values, the results were divided into four classes that range from the relatively highest to the relatively lowest tectonic activity. The drainage basin area between Honaz Fault and Mount Honaz is an ideal place to test relative tectonic activity. The Honaz fault that is the north boundary fault of the Honaz Mountain has been divided into the Karateke segment and Honaz segment. The indice values calculated from these segments are triangular facets (Lf / Ls: 0.3-0.46), AF (32-77), HI (0.1-0.6), Vf (0.08-0.7), Bs (1.53-5.06) and $\operatorname{Smf}(1.12-1.41)$. The results of this study exhibit the presence of high to very high tectonic activity especially in the central part of the Honaz Fault. Based the results, the neotectonics played an important role in geomorphic evolution of this part of the Honaz Mountain. In addition to the results obtained, evidence of seismic activity, travertine occurrences due to thermal springs and alluvial fans in front of fault zones support high tectonic activity in the region.
\end{abstract}

Keywords: Honaz fault, Tectonic geomorphology, Relative tectonic activity, Geomorphic indices, Western Anatolian

\section{Introduction}

Geomorphology is a significant tool in tectonic studies when using the geomorphic record. Such record includes several landforms and Quaternary deposits that capture immense amount of information from the last few thousand years and may go back approximately more than two million years [1] Tectonic geomorphology focuses on the contrast between topography and geomorphologic features generated by tectonic activity and the erosional factors caused by surface processes that tend to modify them. Defining the relationship between these processes and interpreting the resulting landscape variations are the main interest of tectonic geomorphology [2]-[3]. The study of landscapes, and surface processes including their description, classification, origin, development, and history, that emphasize the physical, biological, and chemical aspects, is regarded as geomorphology. It may either have a qualitative or a quantitative representation. The quantitative measurement of landscape is based on the calculation of geomorphic indices using
Öz

Bu çalıșmada, Honaz fayının göreceli tektonik aktivitesinin belirlenmesi için, dağ önü sinüslülük oranı (Smf), üçen yüzler, vadi taban genişliğinin vadi yüksekliğine oranı (Vf), drenaj havzası asimetrisi (AF), hipsometrik integral (HI) ve drenaj havzası sekli (Bs) gibi jeomorfik indisler hesaplanmıştır. Indis analizlerinin sonuçları değerlendirilmiş ve daha sonra göreceli tektonik aktivite indisi (Iat) olarak tekrar değerlendirme yapılmıştır. Farklı Iat değerlerine dayanarak, sonuçları nispeten en düșükten en yüksek tektonik aktiviteye kadar dört sınıfa bölünmüstür. Honaz Fayı ile Honaz Dağı arasındaki drenaj havzası alanı, göreceli tektonik aktiviteyi test etmek için ideal bir yerdir. Honaz Dağı'nın kuzey sınır fayı olan Honaz fayı morfolojik olarak Karateke ve Honaz segmentlerine ayrılmıştır. Bu iki segmentte hesaplanan indis değerleri, Smf (1.12-1.41), üçgen yüzeyler (Lf/Ls: 0.3-0.46), Vf (0.08-0.7), AF (32-77), HI (0.1-0.6) ve Bs (1.53-5.06)'dır. Bu çalıșmanın sonuçları Honaz Fayının özellikle orta kesimlerinde çok yüksek ve yüksek tektonik aktivitenin varlığını ortaya koymaktadır. Araştırmanın sonucu, Honaz Dağı'nın bu bölümünün jeomorfik evriminde neotektonizmanın önemli bir rol oynadığını göstermektedir. Elde edilen sonuçların yanı sıra bölgedeki sismik aktivite, sıcak su kaynaklarına bağlı traverten olușumları ve fay hatlarının önündeki alüvyon yelpazelerinin varlığı bölgedeki yüksek tektonik aktiviteyi desteklemektedir.

Anahtar kelimeler: Honaz fayı, Tektonik jeomorfoloji, Göreceli tektonik aktivite, Jeomorfik indis, Güneybatı Anadolu

topographic maps or digital elevation models (DEM), aerial photographs or satellite images, and fieldwork [1].

The close relationship between morphometric indices and tectonics has been introduced in earlier studies and certain classifications were developed [4]-[7].

In regions under active extensional tectonics, (e.g. as in Aegean province, normal faults, which are divided into segments, are characteristic and shed light landscape evolution [8]-[9]. The Honaz Fault, which is interest in this study, is a normal dip slip fault in western Turkey has been investigated in two segments: the Karateke and Honaz segment (Figure 1). Similar geomorphological studies segment have been carried out both on normal and strike-slip fault systems [10]-[15].

In the study performed by [14], tectonic evaluations have been made using geomophic indices. In this article, relative tectonic activity indice (Iat) in addition to [14]. This indice, proposed by [7], was obtained by taking statistical averages of all the results that were yielded. The Iat indice results have also been studied and discussed to determine the level of tectonic activity by dividing into different ranges. The results obtained from the 
Karateke and Honaz segments forming the Honaz fault show that these two segments have given different geomorphological results and different relative tectonic activity.

The aim of this study is to identify tectonic and morphological features by using morphometric indices calculated for a mountain front that is bounded by the Honaz Fault and drainage areas between the fault and northern slope of the adjacent Honaz Mountain (Figure 1). In addition, indices calculated have been classified in accordance with the tectonic activity classification suggested by [7].

\section{Regional geology and tectonics}

The Denizli extensional basin is one of the well-known depression in Western Turkey, located at the intersection of the Gediz and Büyük Menderes grabens [16]-[20]. The NW trended Denizli basin is bounded by the Pamukkale fault in the North and Babadağ and Honaz Faults in the south. The Honaz Fault bounds the northern part of the Honaz Mountain, which is the highest one in the Aegean region with an elevation of 2571 meters. The fault has a total length of $13 \mathrm{~km}$ and has been studied in two segments. The first segment is situated in the west and is Karateke segment [21]. The second one called an Honaz segment is situated to the east (Figure 1b).

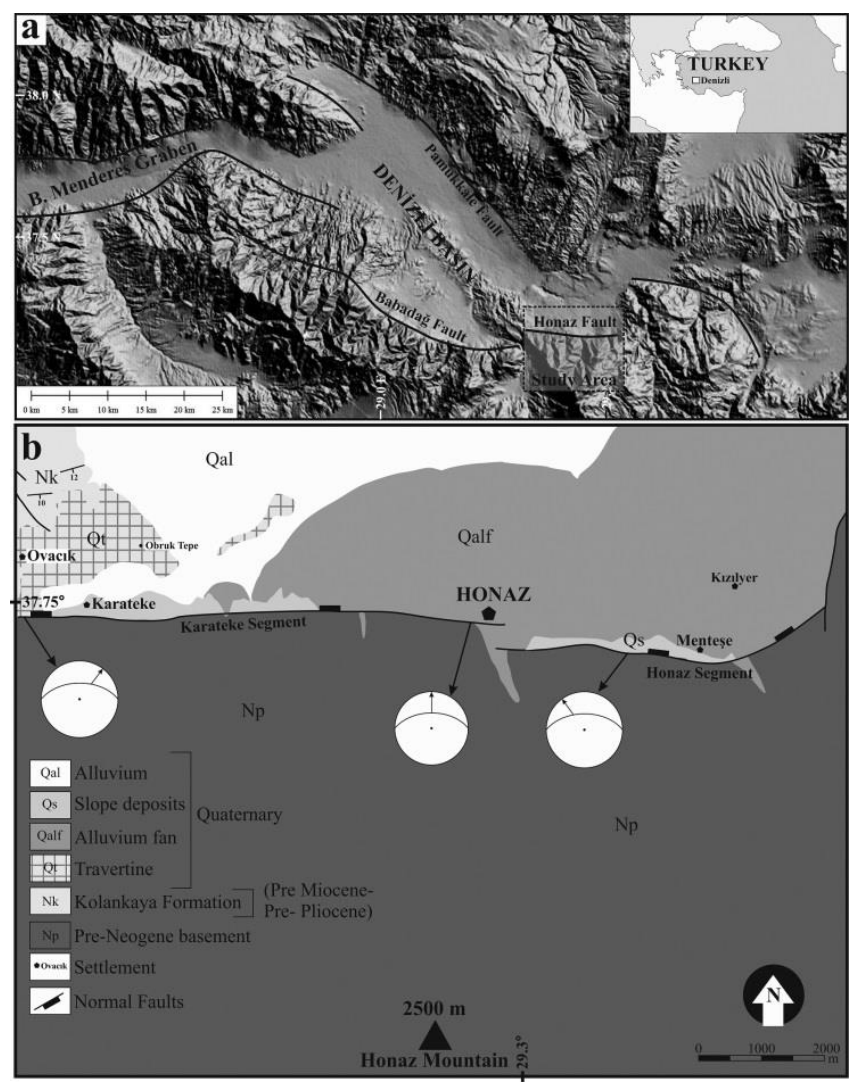

Figure 1: (a): Tectonic outline of the Denizli Basin and location of the study area. (b): Simplified geological map of the Honaz Fault [22].

At the footwall of the Honaz Fault, metasediments, Mesozoic allochthonous units of Lycian Nappes such as ophiolite, limestone, dolomite, and gypsum are exposed [23]-[24]. They are allochtonous, and are imbricated and thrusted internally. The gypsum beds are black to dark gray in color. Their measurable thickness is about $300 \mathrm{~m}$ and the beds were intensely deformed and folded [23]-[24]. According to
$87 \mathrm{Sr} / 86 \mathrm{Sr}$ data that ranges between 0.707761 and 0.707772 . [24], obtained a Late Triassic age from the gypsum exposure that intercalates with dolomite at the south of Kizllyer (Figure 1b). The age of the successions, overlying these metamorphics, i.e. known as the Honaz Shale, ranges, in general, from Triassic to Paleocene [25]. The Honaz Shale, take places at footwall of the fault, consists of low grade metamorphic rocks such as phyllite, slate and calcschist [21]. N$\mathrm{S}$ trending folded structures have been developed within the metamorphic rocks and resulted from compressional tectonics [26]. Possible age of the metamorphic units was given as Upper Paleozoic by [25] which correlates with the uppermost levels of the Menderes massif. The ophiolitic unit, usually composed of harzburgite, serpentinite, gabro-diabase dykes, crops out in the southeast part of the Honaz Mountain [26]. The ophiolitic units that overthrusted the Eocene-Oligocene units are unconformably covered by late Miocene-late Pliocene units [27]. A Mesozoic allochtonous overlies the metamorphics carbonate succession and has been imbricated and thrusted internally. Age of this succession is Triassic-Paleocene [25]. The gypsum beds are black to dark gray in color, their measurable thickness is about $300 \mathrm{~m}$. and the beds were deformed and folded intensely [23]-[25]. At the hanging wall of the Honaz Fault, the late Miocene to late Pliocene deposits of fluviolacustrine origin and alluvium, alluvial fans, slope debris and travertines of Quaternary age exposed [19]-[27]. The Quaternary deposits rest on the late Miocenelate Pliocene sediments with an angular unconformity (Figure 1b, Figure 3).

\section{Tectonic outlines of the Honaz fault}

The Honaz Fault, one of the southern boundary faults of the Denizli Basin and still active, has generated earthquakes that are recorded in historical and instrumental periods [22]-[28]-29]. The fault is approximately E-W oriented and has a length of $13 \mathrm{~km}$ totally. The first segment, observed between Karateke and Honaz is $7 \mathrm{~km}$ long and named as 'Karateke fault' [21] (Figure 1b). The second one, passing through the town of Honaz, extends toward the Kizılyer village to the east (Figure 1b). The fault planes on the Honaz segment of $6 \mathrm{~km}$ long are very obvious (Figure 1b).

The fault planes observed on the Honaz segment are E-W trending and their dips are oriented to the north and range between $40^{\circ}$ and $60^{\circ}$. Fault breccia and signs of oxidation along the Karateke segment have been observed and dip of the fault plane varies from $71^{\circ}$ to $88^{\circ}$ (Figure 2 ).
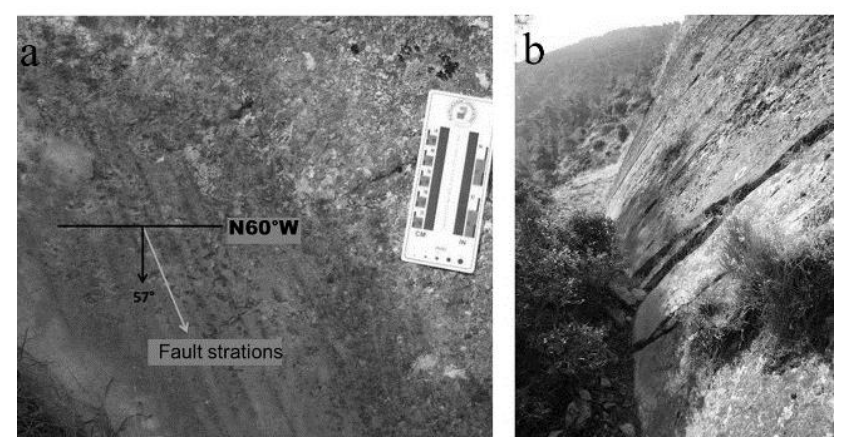

Figure 2: (a): Fault plane and slickenlines, measured on the Honaz fault segment, showing a lateral strike-slip component

(b): General trend of Honaz Fault (between Honaz and Menteşe, see Figure $1 \mathrm{~b}$ for location). 
Fault planes have been measured by vertical component at the centrum of Honaz, right-lateral component at the south of Ovacık and left-lateral component to the west of Menteşe village (Figure 1b). Extensive alluvial fans developed along west of the fault. Looking at historical and recent earthquakes, the Honaz Fault is still active seismically [29]. In a study performed by [28], the calculated amount of the Honaz Fault was 121 meters in a southern direction. Consequently, this situation explains why the alluvial fans cover extensive areas. In addition, several warm thermal spring waters emerged along the Karateke segment in the west, rich in calcium bicarbonate, precipitated travertine-tufa deposits [19]-[30].

Based on the historical and instrumental earthquake records, the Denizli basin has a moderate seismic activity with magnitude up to 6.0 [31]. For instance, the ancient city of Hierapolis at Pamukkale, located along the northern boundary fault (called as Pamukkale fault segment) of the Denizli Basin, was damaged several times by the earthquakes [32]-[33]. Normal faulting, which has a small amount of strike-slip component, is widespread along these boundary faults [34]. Most of the earthquakes occurred in the basin have focal depths of 5 to $15 \mathrm{~km}$ [35]. According to seismic records of the instrumental period, the magnitude of the biggest earthquake that occurred along the Honaz fault zone was measured as Ms=5.7 and occurred on June 13, 1965. The last event with magnitude Ms=5.2 occurred on April 21, 2000 on the same fault zone [36].

\section{Method}

Geomorphic indices are very useful materials to determine the relative tectonic activity in a region. In this study, geomorphic indices were calculated to determine the relative tectonic activity of the Honaz Fault. In these calculations, 6 main parameters such an Smf, percentage faceting, Vf, AF, HI, and Bs, were taken into account. Geomorphic indices, formulas and descriptions that used in this study were given in Table 1 . The DEM data with a resolution of $10 \mathrm{~m}$ have been used in order to calculate the geomorphic indices obtained from the maps of $1 / 25000$ scale. The DEM data were processed and the calculations were made using Mapinfo, ArcGis and Global Mapper GIS-programs.

In addition, it has been checked by the Kolmogorov-Smirnov (K-S) test if statistical differences are present in the HI values that were calculated in the valleys bounded by the Honaz segment and Karateke segment. All the results provided from the geomorphic indices were statistically evaluated considering the index of relative active tectonic (Iat) proposed by [7].

\section{Results}

Geomophic indices are frequently used to determine both topographic analysis and relative tectonic activity. Different indices are used during the analysis of mountain fronts and drainage areas. Indices used for the active tectonics could determine the different anomalies along the mountain fronts and drainage areas. These anomalies could have been resulted from local tectonic activity, uplift or subsidence. The indice values yielded were used in order to analyze the drainage areas between the Honaz Mountain and the Honaz Fault. and to divide into tectonic classes based on the value intervals of the indices. In consequence, the calculated indices were collected, averaged, and used for classification of the relative tectonic activity in the study area.

\subsection{Mountain front}

For determining the geomorphology of the mountain, at the northern part of the Honaz Mountain, mountain front sinuosity and triangular facets were calculated along the segments of Karateke and Honaz (Figure 3).

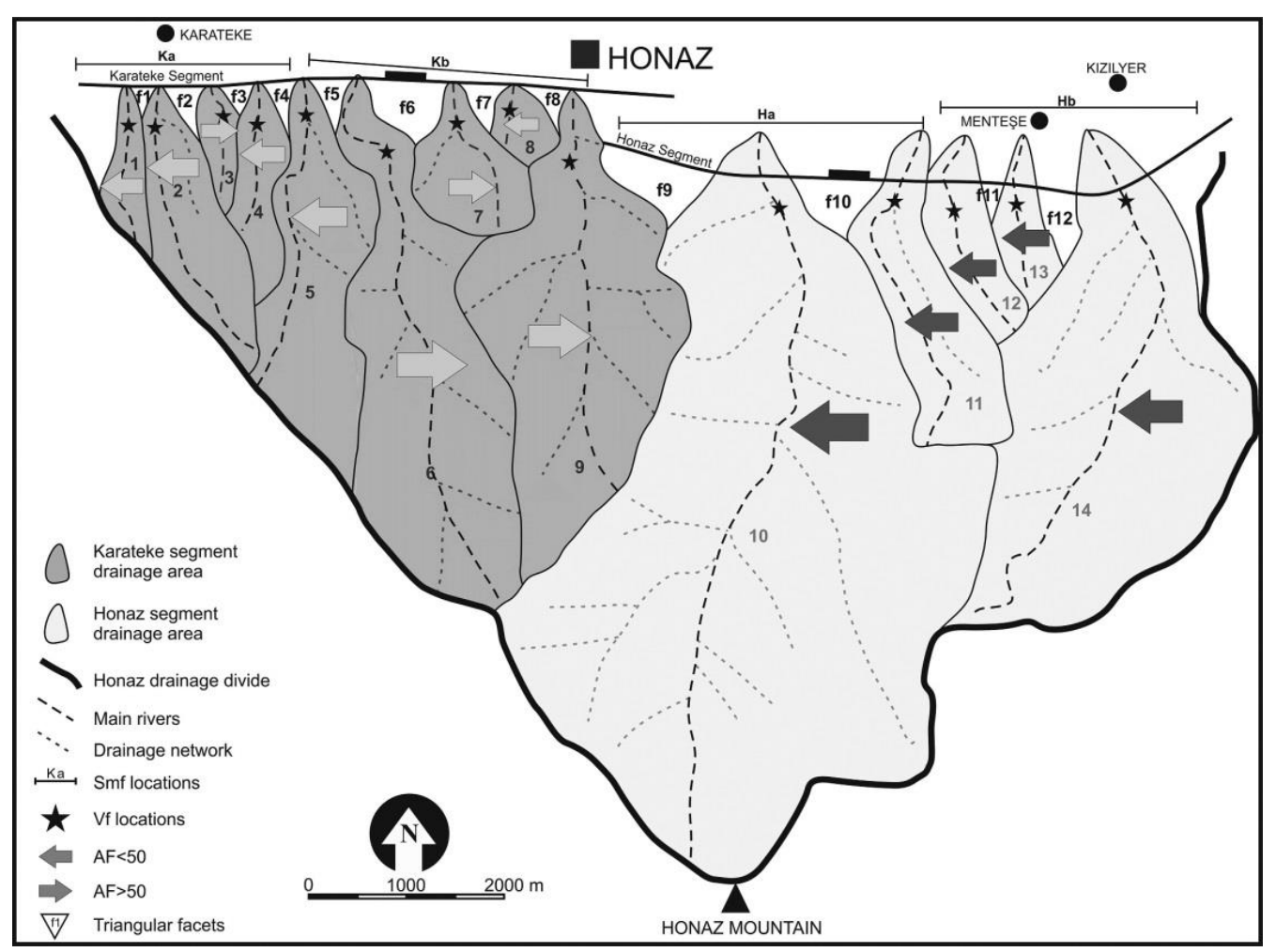

Figure 3: A schematic map that displays the main geomorphic indices calculated in this work. 
Table 1. Morphometric parameters used in tectonic landscape analysis of Honaz Fault (modified from [37].

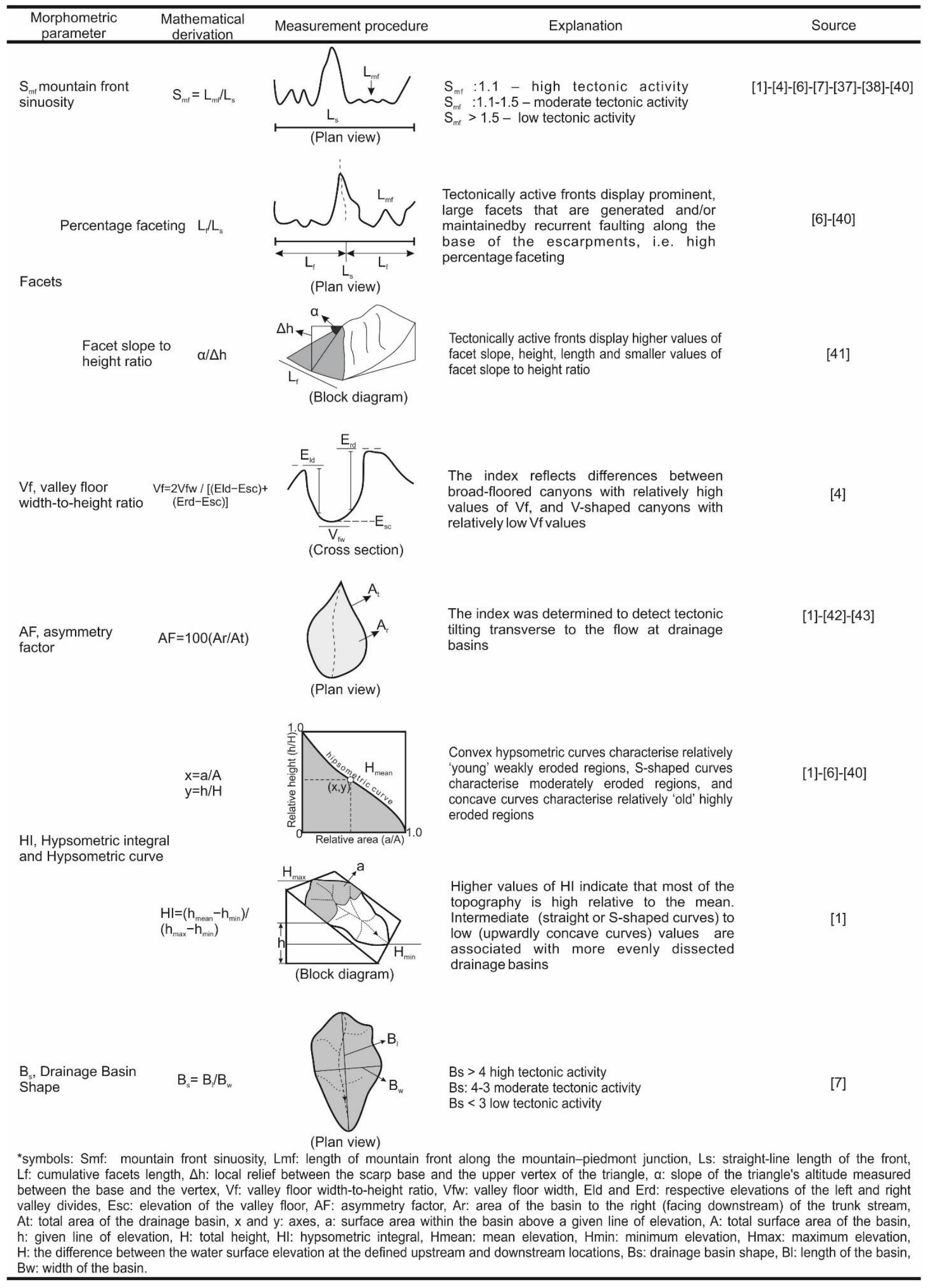




\subsubsection{Mountain front sinuosity (Smf)}

In four different areas, the mountain fronts have been calculated along the Karateke and Honaz segments for the north of the Honaz Mountain. According to these calculations, the smf values range from 1.12 to 1.41 (Figure 3) (Table 2).

\subsubsection{Triangular facets}

Twelve triangular facets were calculated for the areas restricted by the Karateke and Honaz segments. Average slope dip and height are calculated as $22.07^{\circ}$ and $285.3 \mathrm{~m}$, respectively. Among the data calculated, facet 13 is $1200 \mathrm{~m}$ high and facet 12 has the highest dip value. Average dip-height ratios are 0.11 for the Karateke segment, and 0.06 for the Honaz segment. Widths of the triangular facets are between 350 $1050 \mathrm{~m}$ with an average of $732.6 \mathrm{~m}$.

\subsection{Drainage system of the Honaz mountain}

Drainage system of the Honaz Mountain consists of drainage areas, each ranging up to $20 \mathrm{~km}^{2}$ spatially. In general, flow directions of the main streams were developed perpendicular to the Honaz Fault. Maximum flow lengths of the streams in the drainage areas, shown in dashed lines in Figure 3, change between 1 and $8 \mathrm{~km}$. All the streams are ephemeral except one i.e. drainage area 10. Drainage areas located in the central part of the Honaz Fault are bigger than those at the margins (Figure 3).

\subsubsection{Valley floor width-to-height ratio (Vf)}

In order to determine the Vf index, calculations have been carried out, $200 \mathrm{~m}$ up valley in the small valleys, $500 \mathrm{~m}$ up valley in the large valleys, with respect to the fault. In the calculations carried out along the Honaz Fault, the Vf values are 0.08-0.7. Large values $(>0.2)$ of Vf were calculated in the drainage areas of 1. 2. 3. 4. 5. 6. 7. 8. 11 and 14 whereas small values were calculated in the drainage areas of 9.10.12 and 13 (Figure 3) (Table 3).

Table 2: Smf and Lf/Ls values for the mountain front which are bounded by Karateke and Honaz segments. For each main front, the mean values are also indicated.

\begin{tabular}{ccccc}
\hline Segment & $\mathrm{S}_{\mathrm{mf}}$ & Mean S $\mathrm{mf}_{\mathrm{f}} / \mathrm{L}_{\mathrm{s}}$ & 0.3 & $\mathrm{Mean} \mathrm{L}_{\mathrm{f}} / \mathrm{L}_{\mathrm{s}}$ \\
\hline \multirow{2}{*}{ Karateke } & 1.12 & \multirow{2}{*}{0.14} & 0.46 & 0.38 \\
& 1.16 & & 0.23 & 0.33 \\
Honaz & 1.25 & 1.33 & 0.44 & 0.33 \\
\hline
\end{tabular}

Table 3. Morphometric data and tectonic activity class in the study area.

\begin{tabular}{|c|c|c|c|c|c|c|c|c|c|c|c|c|}
\hline Segment & $\begin{array}{l}\text { Drainage } \\
\text { basin }\end{array}$ & $\mathrm{S}_{\mathrm{mf}}$ & $\begin{array}{l}\text { Class of } \\
\text { Smf }\end{array}$ & $V_{f}$ & $\begin{array}{c}\text { Class of } \\
V_{f}\end{array}$ & $\begin{array}{c}\mathrm{AF} \\
(50-\mathrm{AF})\end{array}$ & $\begin{array}{c}\text { Class of } \\
\mathrm{AF}\end{array}$ & $\mathrm{Hi}$ & $\begin{array}{c}\text { Class of } \\
\mathrm{Hi}\end{array}$ & $\begin{array}{l}\text { Facet slope to } \\
\text { height ratio }\end{array}$ & $\mathrm{B}_{\mathrm{s}}$ & Class of $B_{s}$ \\
\hline \multirow{9}{*}{ Karateke } & 1 & 1.045 & 1 & 0.66 & 2 & $72(-22)$ & 1 & 0.51 & 1 & 0.22 & 3.97 & 2 \\
\hline & 2 & 1.006 & 1 & 0.46 & 1 & $76(-26)$ & 1 & 0.45 & 2 & 0.1 & 4.30 & 1 \\
\hline & 3 & 1.053 & 1 & 0.44 & 1 & $48(2)$ & 3 & 0.2 & 3 & 0.18 & 5.61 & 1 \\
\hline & 4 & 1.06 & 1 & 0.7 & 2 & 63 (13) & 2 & 0.1 & 3 & 0.08 & 2.97 & 3 \\
\hline & 5 & 1.04 & 1 & 0.21 & 1 & $77(-27)$ & 1 & 0,2 & 3 & 0.1 & 4.87 & 1 \\
\hline & 6 & 1.005 & 1 & 0.61 & 2 & $49(1)$ & 3 & 0.6 & 1 & 0.06 & 5.06 & 1 \\
\hline & 7 & 1.036 & 1 & 0.31 & 1 & 32 (18) & 1 & 0.2 & 3 & 0.1 & 1.53 & 3 \\
\hline & 8 & 1.048 & 1 & 0.57 & 2 & $76(-26)$ & 1 & 0.51 & 1 & 0.1 & 2.33 & 3 \\
\hline & 9 & 1.174 & 2 & 0.08 & 1 & $43(7)$ & 2 & 0.51 & 1 & 0.05 & 2.59 & 3 \\
\hline \multirow{5}{*}{ Honaz } & 10 & 1.088 & 1 & 0.09 & 1 & $57(-7)$ & 2 & 0.6 & 1 & 0.11 & 2.44 & 3 \\
\hline & 11 & 1.036 & 1 & 0.58 & 2 & $69(-19)$ & 1 & 0.51 & 1 & 0.04 & 4.48 & 1 \\
\hline & 12 & 1.064 & 1 & 0.1 & 1 & $54(-4)$ & 3 & 0.3 & 3 & 0.13 & 2.77 & 3 \\
\hline & 13 & 1.046 & 1 & 0.19 & 1 & $60(-10)$ & 2 & 0.2 & 3 & 0.05 & 3.10 & 2 \\
\hline & 14 & 1.75 & 3 & 0.51 & 2 & $54(-4)$ & 3 & 0.3 & 3 & 0.03 & 2.06 & 3 \\
\hline
\end{tabular}




\subsubsection{Asymmetry factor (AF)}

At the northern part of the Honaz Mountain, the AF indices were calculated for drainage networks located on the footwall of the fault. Tilting directions of the drainage areas have been shown based on the calculated values, which are larger or smaller than 50 (e.g., $\mathrm{AF}>50$ : dip to $\mathrm{W}, \mathrm{AF}<50$ : dip to $\mathrm{E}$ ) (Table 3).

\subsubsection{Hypsometric curve and hypsometric integral (Hi)}

Hypsometric integrals were calculated and hypsometric curves were drawn for 14 different drainage areas located on the footwall of the Honaz Fault. The Hi values, calculated on 9 different drainage areas on the footwall of the Karateke segment area are 0.1-0.6, whereas the Hi values are 0.2-0.6 for 5 drainage areas on the footwall of the Honaz segment. High Hi values at the drainage areas of the region generally form convex hypsometric curves, while the moderate and low values represent S-shaped and smooth curves (Figure 4).

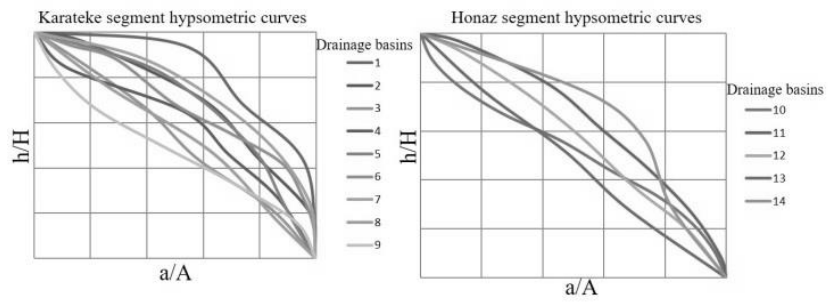

Figure 4: Hypsometric curves for the drainage basins that were bounded by Karateke and Honaz segments.

According to a Kolmogorov-Smirnov (K-S) test, there is no significant difference in Hi values which are calculated from the areas of Karateke and Honaz segments (Figure 5). The presence of high Hi values, along two segments indicates that these areas are relatively young and weakly eroded.

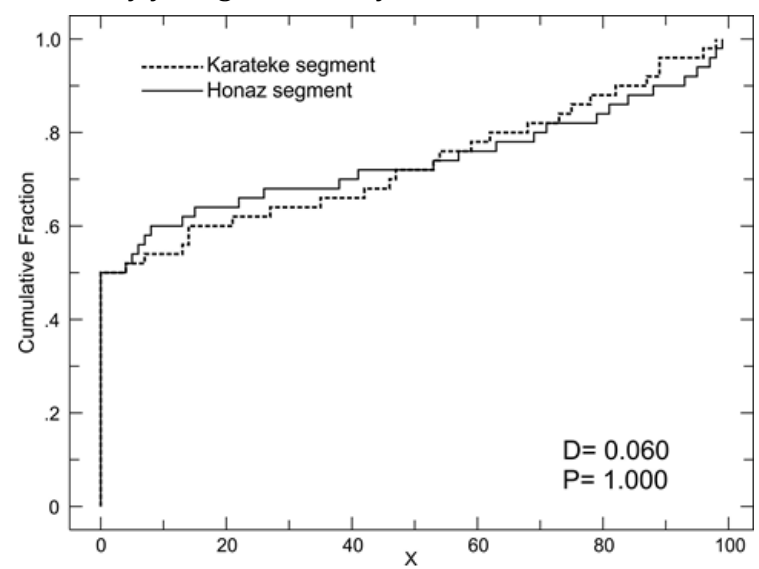

Figure 5: Kolmogorov-Smirnov (K-S) test results of the hypsometric integral values of Karateke and Honaz segments.

\subsubsection{Shape of the drainage basins (Bs)}

The Bs index was calculated for 14 drainage areas. The Bs values vary between 1.37 and 5 . The highest Bs values have been observed in the drainage area 6 and 11 (Table 3).

\section{Discussions}

Various authors differentiated tectonic activities of the certain regions in different tectonic classes using geomorphic indices. Based on Smf values, [7], separated tectonic activity in three different classes: class I $(\mathrm{Smf}<1.1)$, class II $(1.1 \leq \mathrm{Smf}<1.5)$, and class III $(\mathrm{Smf} \geq 1.5)$ (Table 3$)$. Smf values $<1.4$ indicate tectonically active mountain fronts [5]-[38]. Higher Smf values $(<3)$ are related to inactive mountain fronts. Whereas mountain fronts related to active uplift have relatively smooth and low Smf values, Smf values of 1.4-3.0 and 1.8-5 correspond to low active and inactive regions, respectively. In case of a low or a completely stopped uplift ratio, erosional processes start and form sinuous mountain fronts that are smoothed in time [38]. According to [6], linear mountain fronts have Smf values $<1.5$ and reflect basic geomorphic and structural characteristics of tectonically active terrains (class I).

Whereas, irregular mountain fronts, in which Smf values vary between 1.8 and 2.3, represent the regions of class II.

The Smf values that have been calculated for the study area, are approximately 1.14 for the Karateke segment and 1.33 for the Honaz segment. In the Smf calculations for each valley in the study area, apart from valley 9 and 14, the values are lower than 1.1, corresponding to class I of [7]. These values display that the area is significantly active in aspect of tectonic.

Along tectonically active mountain fronts, clear and large triangle surfaces are seen. In tectonically less active regions, on the other hand, small and uncertain triangle surfaces develop [2]. When the triangle facets are compared, those on the Honaz segment are wider and more certain than those on the Karateke segment. This case indicates that the Honaz segment is more active in tectonic.

In the narrow and deeply incised valleys, Vf values are small and related to uplifting [1]. [7] divided the Vf values into three classes: class I: $\mathrm{Vf} \leq 0.5$; class II: $0.5 \leq \mathrm{Vf}<1.0$ and class $\mathrm{III}: \mathrm{Vf} \geq 1$. According to [39], $\mathrm{V}$-shaped valleys $(\mathrm{Vf}<0.6)$ point out active incision, in contrast U- shaped valleys (Vf: 0.3-0.80) indicate valley bottom filling. The low Vf values calculated from the study area imply that the drainage network is V-shaped, which is indicative of deeply incised valleys. Based on these data, tectonic activity has encouraged the valley development accompanying by uplifting in the region.

In development of basin asymmetry, structural control of the cleavage orientation of or bedding could play an important role [7]. Inclination of cleavage or bedding preferably enables the valleys to migrate in the down-dip direction, generating an asymmetric valley. Therefore, these values, which have been obviously influenced from the rock structures, should be disregarded. Depending on the classification scheme of [7], |AF$50|>15| A F-50 \mid,=7-15$ and $|A F-50|<7$ values indicate that high-, medium- and low tectonic activity, respectively. Based on the $\mathrm{AF}$ values in the study area, tilting of the Honaz segment is oriented towards the west, in contrast, there is an irregularity along the Karateke segment.

Low values of Bs indicate a more circular basin in shape, usually accompanied by low tectonic activity. Rapidly uplifted mountain fronts cause elongated, steep basins; and when tectonic activity is diminished or stopped, widening of the basins happens that start from the mountain front [7]-[37]. In their study, [7] proposed three different tectonic classes using the Bs values.

In this classification, Bs values of $>4$ are usually accompanied by relatively higher tectonic activity (class I), Bs values of 4-3 are have been assigned to medial tectonic activity (class II), and 
Bs values of $<3$ were regarded as a result of low tectonic activity (class III).

Looking at the Bs values of the studied area, the highest values, corresponding to higher tectonic activity, have been measured in the areas 1, 6 and 11 (Figure 3). Low and moderate values for the other areas indicates a circular drainage area pattern. The circular drainage pattern shows that there is no very fast uplift in this region.

\section{Discussion of relative tectonic activity based on geomorphic indices}

In this study, the method proposed by [7] was used to assessment the index values over the studied area that represents the relative tectonic activity (Iat). We divide the various indices into three classes, with class one reflecting high tectonic activity and class three representing low activity (Table 3). The Iat was obtained by averaging the different classes of geomorphic indices S/n (S: total of class of indices results, $\mathrm{n}$ : total indices number) and divide them into four classes, in which class 1 corresponds to a very high tectonic activity with values of $\mathrm{S} / \mathrm{n}$ ranging between 1 and 1.5 ; class 2 to a high tectonic activity with values of $S / n>1.5$ but $<2$; class 3 to moderately tectonic activity with $\mathrm{S} / \mathrm{n}>2$ but $<2.5$; and class 4 to a low tectonic activity with values of $S / n>2.5$.

The average of the indices $\mathrm{S} / \mathrm{n}$ and Iat values that are used in active tectonics and that are measured for 14 drainage areas of the study area (see Figure 3 for basin locations) have been summarized in Table 4 . From the obtained Iat values, the areas have been designated to show a relative tectonic activity (Figure 6).

Based on the Iat classification for an area of $55.03 \mathrm{~km}^{2}$, Iat class 1 is very high relative tectonic activity with a value of $19.8 \%$ $\left(10.9 \mathrm{~km}^{2}\right)$, Iat class 2 is high relative tectonic activity with a value of $61.6 \%\left(33.9 \mathrm{~km}^{2}\right)$, Iat class 3 is moderate tectonic activity with a value of 3 to $2.8 \%\left(1.6 \mathrm{~km}^{2}\right)$ and Iat class 4 is low tectonic activity with a value of $15.8 \%\left(8.7 \mathrm{~km}^{2}\right)$ (Figure 6).

The Iat calculated for the study area amounts $81.4 \%$. This corresponds to a high to very high tectonic activity. The areas with highest values correspond to the middle parts of the Honaz Fault. Consequently, the middle part this normal fault has greater dip-slip.

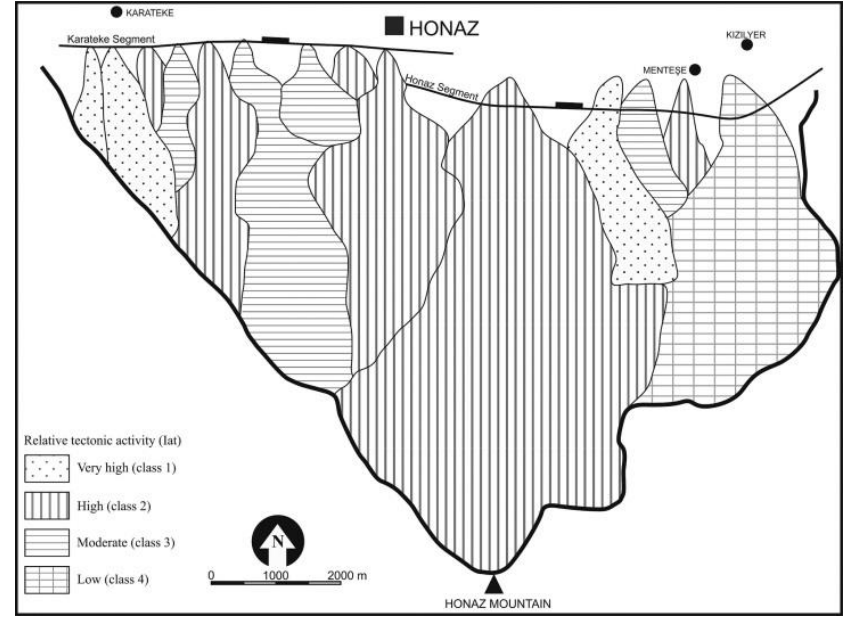

Figure 6: Distribution of the Iat index of relative active tectonics in the study area.

In different tectonic terrains where great rates of active tectonics are evident, values of indices are different as well as their ranges. Iat values also differ as in boundaries between classes of relative tectonic activity [7]-[44]-[46]. Morfotectonic indices are related to several parameters such as tectonic processes, climate conditions, lithology and size of catchment area [1]. In classification of relative tectonic activity (Iat), selection of these indices could be preferential. Indices of active tectonics may determine anomalies in fluvial systems or mountain fronts. These anomalies may be resulted from local variations that result from tectonic activity due to uplift and subsidence [7]. Assessment of active tectonics by field observations matches well geomorphic indices and Iat values.

In fact, classes 1 and 2 of Iat correspond to the fields that have fault scarps, active mountain fronts, triangle facets, steep hanged valleys, deformed alluvial deposits and deeply incised river valleys along the Honaz Mountain (Figure 6). In Iat indice map of this study (Figure 6), changes occurring in the short distance are related to tectonic processes (i.e. vertical displacement amount resulting at the faulting and uplifting). It is thought that other parameters influencing morphometric indices have secondary effects.

Table 4: Classification of the Iat (relative tectonic activity index) in the study area.

\begin{tabular}{|c|c|c|c|c|c|c|c|c|}
\hline Segment & $\begin{array}{c}\text { Drainage } \\
\text { basin }\end{array}$ & Class of Smf & Class of Vf & Class of $\mathrm{HI}$ & Class of AF & Class of Bs & $\mathrm{S} / \mathrm{n}$ & Iat class \\
\hline \multirow{9}{*}{ Karateke } & 1 & 1 & 2 & 1 & 1 & 2 & 1.4 & 1 \\
\hline & 2 & 1 & 1 & 2 & 1 & 1 & 1.2 & 1 \\
\hline & 3 & 1 & 1 & 3 & 3 & 1 & 1.8 & 2 \\
\hline & 4 & 1 & 2 & 3 & 2 & 3 & 2.2 & 3 \\
\hline & 5 & 1 & 1 & 3 & 1 & 1 & 1.4 & 2 \\
\hline & 6 & 1 & 2 & 1 & 3 & 1 & 1.6 & 1 \\
\hline & 7 & 1 & 1 & 3 & 1 & 3 & 1.8 & 2 \\
\hline & 8 & 1 & 2 & 1 & 1 & 3 & $1 . .6$ & 2 \\
\hline & 9 & 2 & 1 & 1 & 2 & 3 & 1.8 & 2 \\
\hline \multirow{5}{*}{ Honaz } & 10 & 1 & 1 & 1 & 2 & 3 & 1.6 & 2 \\
\hline & 11 & 1 & 2 & 1 & 1 & 1 & 1.2 & 1 \\
\hline & 12 & 1 & 1 & 3 & 3 & 3 & 2.2 & 3 \\
\hline & 13 & 1 & 1 & 3 & 2 & 2 & 1.8 & 2 \\
\hline & 14 & 3 & 2 & 3 & 3 & 3 & 3 & 4 \\
\hline
\end{tabular}




\section{Conclusions}

In grabens such as extensional basins in western Turkey including the Denizli Basin that are bounded by normal faults, geomorphic indices are useful tools to investigate the influence of active tectonic deformation. These indices, which are calculated from a DEM are tools to identify geomorphologic anomalies related to possible tectonic activity. In this study, the DEM data of the Honaz Fault were used and indices of triangular facets, drainage basin asymmetry (AF), hypsometric integral (HI), drainage basin shape (Bs), ratio of valley-floor width to valley height (Vf), and mountain front sinuosity (Smf) have been calculated. The relative tectonic activity (Iat) of the study area, which is a combination of the above indices, divides the relative tectonic activity of a landscape into four classes. According to the calculated Iat indice, $19.8 \%\left(10.9 \mathrm{~km}^{2}\right), 61.6 \%$ (33.9 $\left.\mathrm{km}^{2}\right), 2.8 \%\left(1.6 \mathrm{~km}^{2}\right)$ and $15.8 \%\left(8.7 \mathrm{~km}^{2}\right)$ of the study area respectively corresponds to class 1, 2, 3 and 4 .

Based on these findings, it is concluded that the Honaz Fault has geomorphologically high tectonic activity. These results confirm the usability of morphometric analyses to evaluate regional tectonic activity. However, further detailed studies about tectonics in the study area are necessary. Morphometric studies on the Pamukkale and Babadağ faults, which are other boundary faults of the Denizli Basin, are suggested in order to determine the effect of active tectonics in the region.

\section{Acknowledgements}

This study was financially supported by the Pamukkale University Scientific Research Projects Coordination Unit under the project no 2009FBE005, and this support is gratefully acknowledged. Edward A. Keller and Koen Van Noten are thanked for their helpful suggestions and linguistic revisions. We are also grateful to editor and anonymous reviewers for their comments and improvements to the manuscript

\section{References}

[1] Keller EA, Pinter N. Active tectonics. Earthquakes, Uplift, and Landscape. $2^{\text {nd }}$ ed. New Jersey, USA, Prentice Hall, 2002.

[2] Bull WB. "Geomorphic Tectonic Activity Classes of the South Front of the San Gabriel Mountains". California, U.S. Geological Survey Contract Report, 14, 08-001-G-394, 1978.

[3] Burbank DW, Anderson RS. Tectonic Geomorphology. Blackwell Science, Oxford, 2001.

[4] Bull WB, McFadden LD. "Tectonic Geomorphology North and South of the Garlock Fault, California. In: Geomorphology in Arid Regions". Editors: Doehring DO. Proceedings of Eighth Annual Geomorphology Symposium, State University of New York, Binghamton, USA, 115-138, 1977.

[5] Rockwell TK, Keller EA, Johnson DL. "Tectonic geomorphology of alluvial fans and mountain fronts near Ventura, California". Editors: Morisawa M. Proceedings of the $15^{\text {th }}$ Annual Geomorphology Symposium. Allen and Unwin Publishers, Boston, USA, 183-207, 1985.

[6] Silva PG, Goy JL, Zazo C, Bardajm T. "Fault generated mountain fronts in Southeast Spain: Geomorphologic assessment of tectonic and earthquake activity". Gemorphology, 250(1-3), 203-226, 2003.
[7] El-Hamdouni R, Irigaray C, Fernandez T, Chacón J, Keller EA. "Assessment of relative active tectonics, southwest border of Sierra Nevada (Southern Spain)". Geomorphology, 96(1-2), 150-173, 2008.

[8] Gawthorpe RL, Hurst JM. "Transfer zones in extensional basins-their structural style and influence on drainage development and stratigraphy". Geological Society of London, 150(6), 1137-1152, 1993.

[9] Jackson J, Mckenzie D. "A hectare of fresh striations on the Arkitsa Fault, central Greece". Journal of Structural Geology, 21(1), 1-6, 1999.

[10] Gürbüz A, Gürer ÖF. "Tectonic geomorphology of the North Anatolian fault zone in the Lake Sapanca Basin (Eastern Marmara Region, Turkey)". Geosciences Journal, 12(3), 215-225, 2008.

[11] Topal S. "Quantitative analysis of relative tectonic activity in the Acıgöl fault, SW Turkey". Arabian Journal of Geosciences, 11, 198, 2018.

[12] Erdağ DŞ, Tüysüz O, Akyüz S. “Ecemiş fay zonu'nun morfotektonik özellikleri ve morfometrik analizi". ITÜ Dergisi, 8(5), 67-79, 2009.

[13] Özkaymak Ç, Sözbilir H. "Tectonic geomorphology of the Spildağ 1 High Ranges, western Anatolia". Geomorphology, 173-174, 128-140, 2012.

[14] Özkaymak Ç. "Tectonic analysis of the Honaz Fault (western Anatolia) using geomorphic indices and the regional implications". Geodinamica Acta, 27, 2-3. 2015.

[15] Topal S, Keller EA, Bufe A, Koçyiğit A. "Tectonic geomorphology of a large normal fault: Akșehir fault, SW Turkey". Geomorphology, 259, 55-69, 2016.

[16] Koçyiğit A. "Güneybatı Türkiye ve yakın dolayında levha içi yeni tektonik gelişim". Türkiye Jeoloji Kurumu Bülteni, 27, 1-16, 1984.

[17] Altunel E, Karacabak V. "Determination of horizontal extension from fissureridge travertines: a case study from the Denizli Basin, Southwestern Turkey". Geodinamica Acta, 18, 333-342, 2005.

[18] Kaymakçı N. "Kinematic development and paleostress analysis of the Denizli Basin (Western Turkey): implications of spatial variation of relative paleostress magnitudes and orientations". Journal of Asian Earth Sciences, 27, 207-222, 2006.

[19] Özkul M, Kele S, Gökgöz A, Shen CC, Jones B, Baykara MO, Fórizs I, Nemeth T, Chang YW, Alçiçek MC. "Comparison of the quaternary travertine sites in the Denizli extensional basin based on their depositional and geochemical data". Sedimentary Geology, 294, 179-204, 2013.

[20] Van Noten K, Soete J, Claes H, Foubert A, Özkul M, Swennen R. "Fracture networks and strike-slip deformation along reactivated normal faults in Quaternary travertine deposits, Denizli Basin, Western Turkey". Tectonophysics, 588, 154-170, 2013.

[21] Okay Aİ. "Denizli’nin güneyinde Menderes masifi ve Likya naplarının jeolojisi". Maden Tetkik ve Arama Dergisi, 109, 45-58, 1989.

[22] Topal S. Denizli Havzasındaki Fayların Tektonik Jeomorfolojisi. Doktora Tezi, Pamukkale Üniversitesi, Denizli, Türkiye, 2012.

[23] Alçiçek H, Özkul M, Varol B. "Elementary sulphur formation in Kizılyer evaporates and fissure fill gypsum (Denizli, SW Anatolia)". 14th International Petroleum and Natural Gas Congress and Exhibition of Turkey, Ankara, Turkey, 12-14 May 2003. 
[24] Gündoğan İ, Helvacı C, Sözbilir H. “Gypsiferous carbonates at Honaz Dağı (Denizli): First documentation of Triassic gypsum in western Turkey and its tectonic significance". Journal of Asian Earth Sciences, 32, 49-65, 2008.

[25] Çağlayan MA, Öztürk EM, Öztürk Z, Sav H, Akat U. "Menderes Masifi güneyine ait bulgular ve yapısal yorum". Jeoloji Mühendisliği Dergisi, 9-17, 1980.

[26] Bozkuş C, Kumsar H, Özkul M, Hançer M. "Seismicity of Active Honaz Fault under an extensional tectonic regime". International Earth Sciences Colloquium on the Aegean Region, 7-16, 2001.

[27] Alçiçek H, Varol B, Özkul M. "Sedimentary facies, depositional environments and palaeogeographic evolution of the Neogene Denizli Basin of SW Anatolia, Turkey". Sedimentary Geology, 202, 596-637, 2007.

[28] Altunel E. "(Lattivita sismica a Hierapolis e nelle zone limitrofe) Hierapolis ve yakın çevresinde tarihsel deprem aktivitesi". Ricerche Archeologiche Turche Nella Valle Del Lykos (Lykos Vadisi Türk Arkeoloji Araștırmaları), 229-325, 2000.

[29] Koçyiğit A. "The Denizli graben-horst system and the eastern limit of western Anatolian continental extension: basin-fill, structure, deformational mode, throw amount and episodic evolutionary history, SW Turkey". Geodinamica Acta, 18(3/4), 167-208, 2005.

[30] Horvatinčić N, Özkul M, Gökgöz A, Barešić J. "Isotopic and geochemical investigation of tufa in Denizli province, Turkey". Editors: Özkul M, Yağız S, Jones B. Proceedings of International Symposium on Travertine, sedimentology session, 21-25 September 2005, Denizli, Turkey, 162-170, 2005.

[31] Hancock PL, Chalmers RML, Altunel E, Çakır Z. "Travitonics: using travertines in active fault studies". Journal of Structural Geology, 21, 903-916, 1999.

[32] Altunel E, Barka A. "Hierapolis'teki arkeosismik hasarların değerlendirilmesi (Evaluation of archaeoseismic damages at Hierapolis)". Geology Bulletin of Turkey, 39, 65-74, 1996.

[33] Piccardi L. "The AD 60 Denizli basin earthquake and the apparition of Archangel Michael at Colossae (Aegean Turkey)". Geological Society of London, 273, 95-105, 2007.

[34] Irmak TS. "Focal mechanisms of small-moderate earthquakes in Denizli Graben (SW Turkey)". Earth Planets Space, 65, 943-955, 2013.

[35] Kaypak B, Gökkaya G. "3-D imaging of the upper crust beneath the Denizli geothermal region by local earthquake tomography, western Turkey". Journal of Volcanology and Geothermal Research, 211-212, 47-60, 2012.
[36] Tan 0, Tapırdamaz MC, Yörük A. "The Earthquake Catalogues for Turkey". Turkish Journal of Earth Sciences, 17(2), 405-418, 2008.

[37] Ramirez-Herrera MT. "Geomorphic assessment of active tectonics in the Acambay graben, Mexican volcanic belt". Earth Surface Processes and Landforms, 23, 317-332, 1998.

[38] Keller EA. "Investigation of active tectonics: use of surficial earth processes. In: Active Tectonics". Studies in Geophysics, Editors: Wallace RE. National Academy Press: Washington DC. 136-147, 1986.

[39] Pérez-Peña JV, Azor A, Azañón JM, Keller EA. “Active tectonics in the Sierra Nevada (Betic Cordillera, SE Spain): insights from geomorphic indexes and drainage pattern analysis". Geomorphology, 119, 74-87, 2010.

[40] Wells SG, Bullard TF, Menges CM, Drake PG, Karas PA, Kelson KI, Wesling JR. "Regional variations in tectonic geomorphology along a segmented convergent plate boundary pacific coast of Costa Rica". Geomorphology, 1, 239-265, 1988.

[41] Petit C, Meyer B, Gunnell Y, Jolivet M, Sanikov V, Strak V, Gonga-Saholiariliv N. "Height of faceted spurs, a proxy for determining long-term throw rates on normal faults: Evidence from the North Baikal rift system, Siberia". Tectonics, 28, 6010, 2009.

[42] Cox RT. "Analysis of drainage-basin symmetry as a rapid technique to identify areas of possible Quaternary tiltblock tectonics: an example from the Mississippi Embayment". Geological Society of America Bulletin, 106, 571-581, 1994

[43] Hare PW, Gardner, TW. Geomorphic Indicators of Vertical Neotectonism Along Converging Plate Margins, Nicoya Peninsula, Costa Rica". Editors: Morisawa M, Hack JT. Tectonic Geomorphology: Proceedings of the $15^{\text {th }}$ Annual Bighamton Geomorphology Symposium. Boston, USA, 75-104, 1985.

[44] Dehbozorgi M, Porkermani M, Arian M, Matkan AA, Motamedi H, Hosseiniasl A. "Quantitative analysis of relative tectonic activity in the Sarvestan area, central Zagros, Iran". Geomorphology, 121(3-4), 329-341, 2010.

[45] Mahmood SA, Gloaguen R. "Appraisal of active tectonics in Hindu Kush: Insights from DEM derived geomorphic indices and drainage analysis". Geoscience Frontiers, 3-4, 407-428, 2012.

[46] Faghih A, Samani B, Kusky TM, Khabazi S, Roshanak R. "Geomorphologic assessment of relative tectonic activity in the Maharlou Lake Basin, Zagros Mountains of Iran". Geological Journal, 47, 30-40, 2012. 